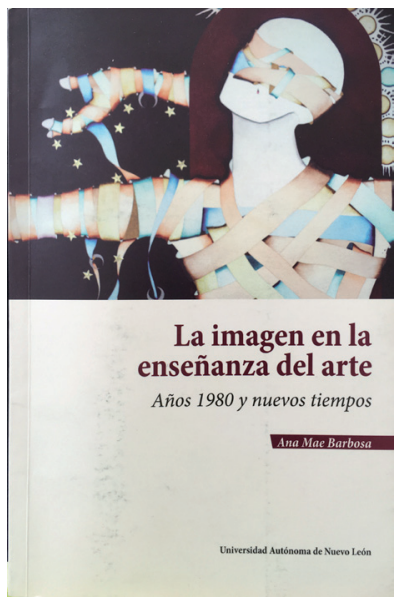

La imagen en la enseñanza del arte. Años 1980 y nuevos tiempos

Ana Mae Barbosa

Año: 2015 Lugar: Monterrey, México.

Editorial Universidad Autónoma de Nuevo León

Páginas: 145

ISBN: 978-607-27-0547-0

\title{
Políticas de educación artística en países americanos: el abordaje triangular
}

El trabajo de Ana Mae Barbosa siempre ha tenido como objetivo la idea de conocer y mejorar las prácticas que se llevan a cabo en educación artística, al mismo tiempo que ha puesto en marcha numerosas iniciativas para integrar los esfuerzos del colectivo de profesionales latinoamericanos inmersos e implicados en las pedagogías del arte. La traducción al castellano de uno de sus trabajos más célebres corre a cargo de otro gran referente internacional, el profesor Ramón Cabrera Salort, quien escribe un capítulo introductorio a manera de prólogo, para presentarnos este documento tan importante. Con su texto titulado "Hacer del arte/educación un inédito viable", Cabrera rinde homenaje a Barbosa; y es que ambos siguen defendiendo la educación artística en todos los foros en los que participan desde hace décadas. Se lamenta Cabrera de que no se haya editado anteriormente ninguna traducción al español de esta investigadora de referencia, ya que sí existen y podemos acceder a otros muchos autores norteamericanos o europeos. Este dato nos da una idea del poco peso que se le había concedido a Brasil en el panorama de la educación artística, siendo como es una potencia de primera fila en lo referido a la pedagogía de las artes. Clarifica el profesor Cabrera que, si bien no existían traducciones del libro, esto no impedía que fuese conocido y usado por los estudiantes universitarios de Cuba y México a través del original en portugués A Imagem no Ensino da Arte.

La formación de Ana Mae debe mucho al papel que desde sus inicios ejerció sobre ella Paulo Freire, con quien trabajó, y con quien comparte la idea de que lo más genuino de nuestra visión del arte en la educación se encuentra atravesado por una dimensión democrática y liberadora. La educación no puede reducirse a una mera transmisión de saberes, ya que implica una puesta en escena que supone el encuentro entre sujetos interlocutores, y por tanto se trata de un acto liberador que implica comunicación y diálogo. También del encuentro fecundo con Freire procede su defensa de la experiencia directa con la realidad y con la cultura del entorno. De hecho, lo que aquí se defiende es que educación no es represión, sino liberación. Es a partir de estas bases liberadoras y descolonizadoras, de esta visión crítica de la 
sociedad, de la cultura y de las artes, que nace el concepto creado y defendido por Barbosa de lo que ella ha denominado el "enfoque triangular".

Con su planteamiento liberador, lo que Ana Mae Barbosa nos demuestra es la necesidad de replantearse la historia, reconociendo así la naturaleza incompleta o silenciada del modo de practicar y construir un matiz dominante de hacer historia del arte. Al dar un nuevo sentido a quienes utilizan el arte en la educación, especialmente en las geografías del Sur, lo que consigue Barbosa es fortalecer las nuevas miradas, superando así las visiones colonizadoras tradicionales, que tanto han preocupado a los países de Latinoamérica, siempre excesivamente pendientes de las novedades que llegaban de Europa o de los Estados Unidos. Barbosa se adelanta a otras sugestivas miradas que también han incidido en la necesidad de generar visiones particulares desde los territorios que habitualmente no tenían voz propia. Se trata de una línea de intereses que conocemos también por los argumentos del ahora mismo tan valorado Luis Camnitzer. La posibilidad de liberación a través de la praxis supone la movilización de la conciencia a partir de un sentido crítico que conduce a la desnaturalización de las formas canónicas de aprender.

Barbosa defiende un acercamiento crítico hacia el arte. Le preocupa que se pierda el trasfondo histórico que debería resultar fundamental para poder disfrutar críticamente del arte. Y es que la ausencia de contacto con patrones de valor del arte, precisamente a través de su historia, impide que aquel que realiza su catarsis emocional por medio del arte sea capaz de convertirse en consumidor crítico de arte. Si el arte no es tratado como forma de conocimiento, sino como "un grito del alma", no estamos haciendo ni educación cognitiva ni educación emocional. En este sentido, sorpresa y satisfacción son criterios aparentemente opuestos que se imbrican dialécticamente. Se muestra escéptica con lo que considera una equivocada división entre estética, crítica e historia, tal y como fue propuesta por la tendencia norteamericana DBAE (Discipline Based Art Education), una metodología que tanto marcó las últimas décadas del siglo XX. Barbosa se siente más cercana a los argumentos de Quentin Bell, quien opta por la apreciación en tanto que posibilidad de leer, analizar y hasta reconocer la obra como un buen ejemplo de un estilo o de una técnica, algo que se denominó en su momento estudios críticos (Critical Studies). Ana Mae fue pionera en la defensa del "otro", de la voz de quien siempre es tratado como minoría (ella es mujer, arte/educadora, proveniente de un país del sur, implicada en una realidad emergente pero siempre oprimida), por ello su construcción del mundo parte de la redefinición del rol de investigador social, reconociendo al otro, implicándose en la investigación como actor social y constructor de conocimiento, asumiendo el carácter histórico, indeterminado, indefinido, no acabado y relativo de los saberes. Ella viene auspiciando desde siempre la multiplicidad de voces, la pluralidad epistémica, la perspectiva de la dependencia y, por tanto, la resistencia; es consciente de la tensión entre minorías y mayorías, atreviéndose con los modos alternativos de hacer y conocer. Para esta importante educadora, la enseñanza de las artes debe contar con la comprensión del arte y sus teorías. 
El concepto de "abordaje triangular" se basa en la necesidad de educar a los educadores, quienes deben ser conscientes de la naturaleza expandida del mundo de las imágenes visuales y su presencia en el conocimiento adquirido de manera informal. Mediante una adecuada formación de estos docentes existe la posibilidad de que, al leer imágenes realizadas por artistas, se prepare al alumnado para observar y comprender el imaginario del mundo que nos rodea. Por otro lado, Barbosa defiende que el público a quien tenemos que formar puede ser de todas las edades y condiciones. No podemos quedarnos con la idea de una educación artística exclusivamente pensada para niños y niñas en edad escolar. Bien al contrario, hemos de considerar beneficiosos para cualquier tipología de usuarios los juicios que provienen de la estética, de la teoría del arte y de la cultura. Tanto es así, que la propia Ana Mae, creadora y divulgadora del concepto de arte/educación (un neologismo que siempre fue más valorado en el ámbito brasileño), llega a concluir: "Eliminemos la designación arte/educación y pasemos a hablar directamente de enseñanza del arte y aprendizaje del arte sin eufemismos".

Además de posibilitarnos un acercamiento a su "abordaje triangular" (apreciar, contextualizar, hacer), este libro nos ofrece otros aspectos muy interesantes que Ana Mae Barbosa ha ido tejiendo a lo largo de su trayectoria, como pueden ser: la educación y la formación de educadores de museos; el asociacionismo entre profesionales de la educación en artes; las diferentes situaciones políticas y sociales que permiten o impiden una fecunda actividad educativa; e incluso la preocupación por mejorar la calidad del panorama cultural, algo que ella descifra especialmente a partir de una realidad que conoce en directo, como es la de Brasil. Teniendo en cuenta todas estas perspectivas, deberíamos reflexionar más sobre nuestro papel en la sociedad. Si reconocemos que el arte constituye una manifestación cultural de primera magnitud, ¿por qué motivo se reservan espacios minúsculos y poco valorados para su aprendizaje? Debemos reivindicar y conseguir una sociedad artísticamente desarrollada. Para lograrlo no basta con disponer de un patrimonio importante y de una producción artística relevante, lo que precisamos es formar adecuadamente a un público exigente y conocedor, un público amplio dispuesto a encontrar en el arte elementos poderosos con los cuales disfrutar, descubrir y manejar sus propios intereses.

Ricard Huerta. Universitat de València 